\title{
En nervetumor ved håndleddet
}

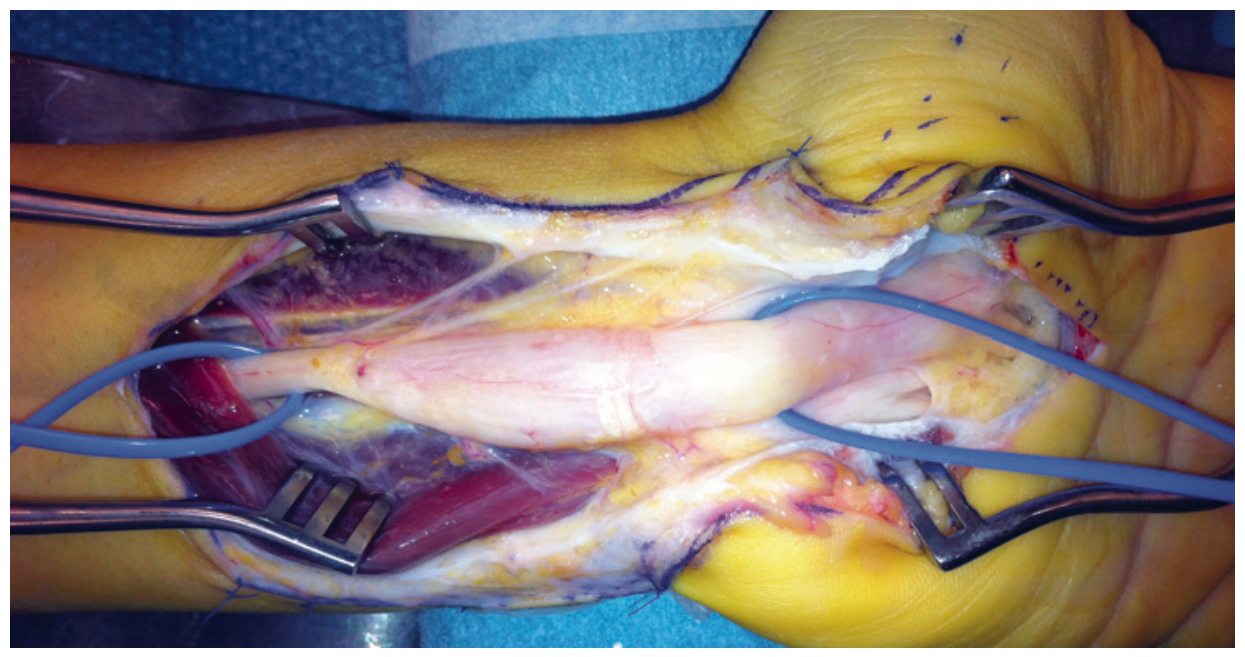

En tidligere frisk jente i tenårene ble henvist til håndkirurgisk avdeling med en kul på bøyesiden ved venstre håndledd. Denne var blitt oppdaget av mor rundt syv år tidligere og var etter hvert blitt økende smertefull. Pasienten beskrev overfølsomhet for berøring og nummenhet i tommel, peke-, lang- og ringfinger. Perkusjon over tumor ga utstrålende smerter og økt nummenhet i de samme fingrene. MR-undersøkelse viste en fortykket medianusnerve med utseende som en kabel på grunn av fibrøs fortykkelse av peri- og endonevrium og økt mengde fett som separerer de ca. 15 nerveaksonene (bilder på nett). Tumorens utbredelse var ca. $10 \mathrm{~cm}$. Tilstanden ble diagnostisert som et lipofibromatøst hamartom på grunn av MR-funnene, som angis som patognomoniske for tilstanden (1).

Det ble gjort eksplorasjon av tumor og dekompresjon av nerven i karpaltunnelen. Bildet viser tumoren, som på det tykkeste hadde $3 \times$ større diameter enn en normal nerve. Ved kontroll to og seks måneder senere hadde pasienten de samme smerteplagene som før operasjonen, men følesansen i fingrene var forbedret. Nevrografi etter to måneder viste moderat aksonal og demyeliniserende sensorimotorisk affeksjon av medianusnerven $\mathrm{i}$ håndledds- $\mathrm{og}$ håndrotsnivå, tydende på kompresjonsnevropati. EMG-undersøkelse viste sparsom denervasjonsaktivitet og funn som ved gjennomgått reinnervasjon. Det var ingen tidligere undersøkelser som man kunne sammenligne med.

Lipofibromatøst hamartom er en sjelden, men godartet neoplasme i perifere nerver. En tredel er assosiert med makrodaktyli. Medianusnerven er hyppigst affisert. Tilstanden presenterer seg oftest med en tumormasse og symptomer på kompresjonsnevropati (smerter, parestesier, tap av følesans og muskelsvakhet). Histologi avdekker modne fettceller og fibrøst bindevev som infiltrerer mellom nervefasiklene. Biopsi frarådes grunnet tap av nervefunksjon og er heller ikke nødvendig da patognomoniske funn ved MRundersøkelse gir diagnosen. Lipofibromatøst hamartom uten symptomer observeres. Tidlig dekompresjon av nerven er anbefalt ved kompresjonsnevropati for å unngå varige nerveutfall. Dette kan gi symptomfrihet, men langtidsresultatene har likevel vist seg å være variable. Fornyet dekompresjon kan bli nødvendig. Makrodaktyli vurderes og behandles særskilt. Behandling bør skje ved en avdeling med håndkirurgisk ekspertise.

Pasientens pårørende har gitt samtykke til at artikkelen blir publisert.

\section{Christer Kjærvik}

Nordlandssykehuset Vesterålen

\section{Hebe Désirée Kvernmo}

hebe.desiree.kvernmo@unn.no

Håndkirurgisk seksjon

Universitetssykehuset Nord-Norge og

Universitetet i Troms $\varnothing$ -

Norges arktiske universitet

\section{Anna Bågenholm}

Røntgenavdelingen

Universitetssykehuset Nord-Norge

\section{Sissel Løseth}

Universitetssykehuset Nord-Norge og

Universitetet i Tromsø -

Norges arktiske universitet
Christer Kjærvik (f. 1986) er under spesialisering i ortopedisk kirurgi.

Forfatter har fylt ut ICMJE-skjemaet og oppgir ingen interessekonflikter.

Hebe Désirée Kvernmo (f. 1961) er dr.med., med mastergrad i helseadministrasjon og ledelse, og spesialist i ortopedisk kirurgi. Hun er seksjonsoverlege i håndkirurgi og professor II.

Forfatter har fylt ut ICMJE-skjemaet og oppgir ingen interessekonflikter.

Anna Bågenholm (f. 1970) er spesialist i radiologi og overlege.

Forfatter har fylt ut ICMJE-skjemaet og oppgir ingen interessekonflikter.

Sissel Løseth (f. 1962) er ph.d., spesialist i klinisk nevrofysiologi og i nevrologi og seksjonsoverlege i klinisk nevrofysiologi. I tillegg er hun førsteamanuensis $\|$

Forfatter har fylt ut ICMJE-skjemaet og oppgir ingen interessekonflikter.

Litteratur

1. Tahiri Y, Xu L, Kanevsky J et al. Lipofibromatous hamartoma of the median nerve: a comprehensive review and systematic approach to evaluation. diagnosis, and treatment. J Hand Surg Am 2013; 38: $2055-67$.

Mottatt 25.1.2016, første revisjon innsendt 25.7. 2016, godkjent 26.9. 2016. Redaktør: Liv-Ellen Vangsnes.

Engelsk oversettelse på www.tidsskriftet.no 